\title{
Primary spinal cord oligodendroglioma. Case illustration
}

\author{
*D. Gürkanlar; **H. Koçak; **A. Aciduman; E. Yucel and Ö. Ekinci
}

*Mustafa Kemal University. School of Medicine. Department of Neurosurgery. Antakya. Turkey: **Social Security Insurance Specialization Education Hospital Neurosurgery Clinic. Ankara. Turkey. Kırıkkale University. School of Medicine. Department of Neurosurgery. Kırıkkale. Turkey. Gazi University, School of Medicine. Department of Pathology. Ankara. Turkey.

\section{Summary \\ Spinal cord oligodendrogliomas are rare pathologies of the spinal cord, and their location at conus and/or filum terminale is even rarer. There are only 7 spinal cord oligodendrogliomas reported in the literature. Our case is the eighth spinal cord oligodendrogliomas at this location.}

KEY WORDS: spinal oligodendroglioma, cauda equina, filum terminale, extramedullary, intradural.

Oligodendroglioma primario de la médula espinal. Caso clínico

\section{Resumen}

Los oligodendrogliomas de la médula espinal son raros y su localización en el cono medular o del filum terminale son aún menos frecuentes. Sólo hay siete oligodendrogliomas de la médula encontrados en la literatura. Nuestro caso es el octavo oligodendroglioma medular con esta localización

PALABRAS CLAVE: Oligodendroglioma medular. Cola de caballo. Filum terminale. Extramedular. Intradural.

\section{Case}

A 56-year-old man suffering from bilateral leg pain for 2 months which especially worsens at nights was admitted to our outpatient clinic. There was no history of urinary incontinence. His neurological examination was unremarkable. The neuroimaging studies including magnetic resonance imaging (MRI) of the lumbar spine revealed an intratechal extramedullary mass of $23 \times 23 \times 13 \mathrm{~mm}$. at $\mathrm{L}_{1-2}$ intervertebral disc level. The mass was isointense on T1weighted images and hyperintense on T2 weighted images with cystic components (Figure1).

The patient was operated upon under general anaesthesia, in prone position, on the operating table. A midline ver-

Recibido:02-06.05. Aceptado: 29-09-05 tical skin incision was made, $\mathrm{L}_{1}$ and $\mathrm{L}_{2}$ total laminectomy was performed. Following laminectomy a midline dura incision was made and the intradural mass exposed. There was partial invasion of conus by the tumor. The mass was dissected easily from the nerve roots and conus by using micro-dissection techniques and resected totally.

Histopathological examination of the resected specimen represented an oligodendroglioma Grade 2.

\section{Discussion}

Primary spinal cord oligodendrogliomas constitutes $2 \%$ of the spinal cord tumors and $1.5 \%$ of the central nervous system oligodendrogliomas ${ }^{4}$. Spinal cord is the anatomic location with the lowest predilection of oligodendrogliomas ${ }^{1}$. There are 50 primary spinal cord oligodendrogliomas reported in the literature ${ }^{3}$. There are 7 reported cases $(17.5 \%)$ in which the tumor was either

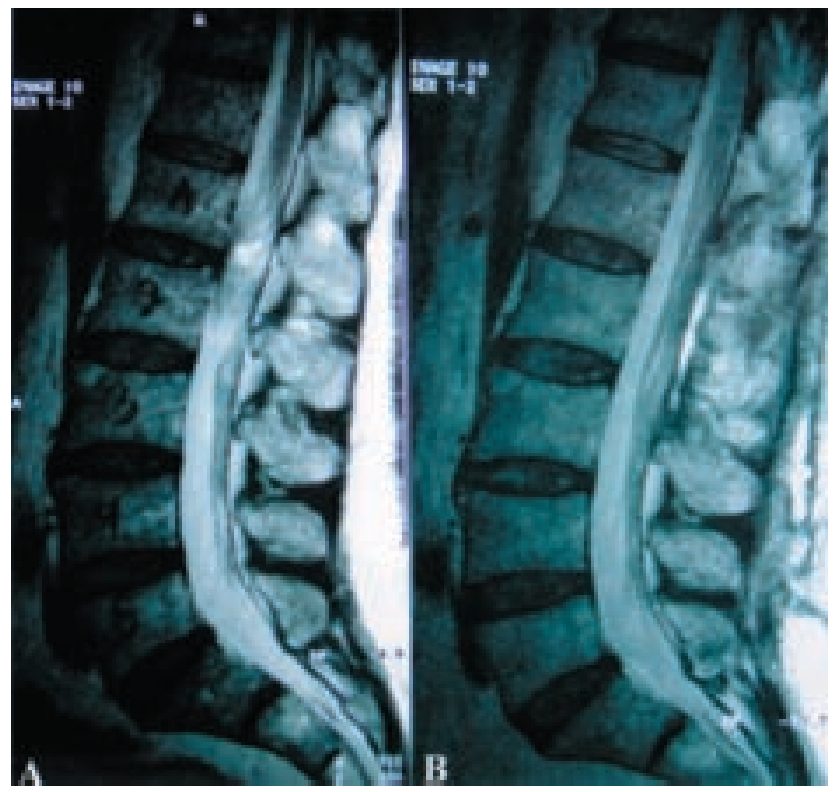

Figure 1 A, B. Hyperintense intradural extramedullary mass on T2 weighted images with cystic components (A). Post-op MRI of the lumbosacral region revealing no residual tumor (B). 
located at conus and/or filum terminale ${ }^{2,3}$. This is the $8^{\text {th }}$ oligodendroglioma in this group of oligodendrogliomas. The surgery of the lesions with conal invasion may result in complications such as urinary incontinence and weakness of the lower extremity ${ }^{2,3,4}$.

Although there was invasion of the conus, total resection of the tumor resulted in improvement of our patients complaints.

\section{References}

1. Enestrom, S., Grontoft, O.: Oligodendroglioma of the spinal cord. Report of one case. Acta Pathol Microbiol Scand, 1957; 40: 396-400.

2. Fortuna, A., Celli, P., Palma, L.: Oligodendroglioma of the spinal cord. Acta Neurochir (Wien) 1980; 52: 305-329.

3. Fountas, K., Karampelas, I., Nikolakakos, L.G., et al.: Primary spinal cord oligodendrogliomas. Case report and review of the literature. Child's Nervous System, 2004.

4. Pagni, C.A., Canavero, S., Gaidolfi, E.: Intramedullary holocord oligodendroglioma. Case report. Acta Neurochir (Wien) 1991; 113: 96-99.

Gürkanlar, D.; Koçak, H.; Aciduman, A.; Yucel, E.; Ekinci, Ö.: Primary spinal cord oligodendroglioma. Case illustration. Neurocirugía 2006; 17: 542-543.

Corresponding address: Doğa Gürkanlar M.D. Mustafa Kemal Universitesi. Rektörlük Konutu No: 6. Antakya. Turkey 